\title{
Evaluation of oxidative stress, antioxidant status and lipid profile in cattle with displacement of the abomasum
}

\author{
Ramazan DURGUT ${ }^{1}$, Aliye SAGKAN OZTURK ${ }^{1}$, Oktay Hasan OZTURK ${ }^{2}$, Murat GUZEL ${ }^{3}$ \\ ${ }^{1}$ University of Mustafa Kemal, Faculty of Veterinary Medicine, Department of Internal Medicine, Hatay; ${ }^{2}$ University of Akdeniz, \\ Faculty of Medicine, Department of Biochemistry, Antalya; ${ }^{3}$ University of Ondokuz May1s, Faculty of Veterinary Medicine, \\ Department of Internal Medicine, Samsun, Turkey.
}

Summary: The aims of the present study were to evaluate serum oxidative and antioxidant status and oxidative stress index, and lipid metabolism profile in cattle with abomasal displacement. A total of thirty-two dairy cows with right- and left-sided abomasal displacement (LDA ( $\mathrm{n}=11)$ and RDA without volvulus $(\mathrm{n}=11)$ ) and 10 healthy controls were used in this study. Serum total oxidative status (TOS) and total antioxidant capacity (TAC) were measured by a colorimetric method. The TOS-to-TAC ratio was also calculated as oxidative stress index (OSI) value. Serum lipid profiles were determined by conventional measurement methods as well. Mean TOS and OSI values were significantly ( $\mathrm{p}<0.001)$ higher in cows with RDA compared to LDA and healthy controls; however, there was no significant differences in serum TAC values among groups. Serum total cholesterol (TC), high density lipoproteins (HDL) and low density lipoproteins (LDL) levels were significantly $(\mathrm{p}=0.001)$ decreased, while serum triglyceride (TG) levels were significantly increased in dairy cows with right- and left-sided abomasal displacement compared to healthy controls. The results of current study showed that dairy cows with RDA forming free radicals than LDA and controls due to abomasal tension and increased intraluminal pressure.

Key words: Dairy cow, displacement abomasum, oxidative stress.

\section{Abomazum deplasmanlı sığırlarda oxidatif stres, antioksidatif seviye ve lipit profilinin değerlendirilmesi}

Özet: $\mathrm{Bu}$ çalışmanın amacı abomazum deplasmanlı sı̆̆ırlarda serum oksidan ve antioksidant seviyeleri ve okidatif stres indeksini (OSI) değerlendirmektir. Bu çalışmada toplam sağa ve sola abomasum deplasmanı olan 32 (11 sola deplasman, 11 volvulus olmayan sağa deplasman) ve 10 sağlıklı Holstein sığır kullanıldı. Serum toplam oksidan seviye (TOS) ve toplam antioksidan kapasite (TAC) kolarimetrik bir yöntemle belirlendi. OSI değeri, TAC-TOS oranı hesaplanarak belirlendi. Serum lipid profili ise geleneksel yöntemlerle belirlendi. TOS ve OSI değerleri, sola deplasmanlı sı̆̆ırlar ve kontrol grubuyla karşılaştırıldığında sağa deplasmanlı sığırlarda önemli oranda $(\mathrm{P}<0.001)$ yüksek bulundu. Fakat serum TAC değerlerinde gruplar arasında önemli bir fark yoktu. Sağa ve sola deplasmanı olan sütçü sığırlar kontrolle karşılaştırıldığında serum trigliserit (TG) sevisinde önemli bir artış belirlenirken, serum total kolestrol (TC), yüksek dansiteli lipoproteinler (HDL) ve düşük dansiteli lipoprotein (LDL) seviyelerinde önemli bir azalma belirlendi. Bu çalışmanın sonuçlarında, RDA'lı sütçü sığırlar da intraluminal basınç artışı ve abomazumdaki gerginlikten dolayı LDA ve kontrollerden daha fazla serbest radikaller oluştuğu gösterildi.

Anahtar sözcükler: Abomasum deplasmanı, oksidatif stress, sütçü sı̆̆ır.

\section{Introduction}

Oxidative stress could be described as an imbalance between oxidant species and antioxidant at the cellular levels. Cellular proteins, lipids and DNA could be damaged by reactive oxygen, nitrogen and other species formed as a result of compromised oxidative balance; however, the oxidative balance is maintained by several antioxidant systems. Oxidative stress was reported to be involved in several pathological conditions associated with production and thus affect the welfare of farm animals (17). Oxidative stress and antioxidative status are a relatively new, but appears to be an active study field in ruminant medicine (4). Clinical problems of cattle mainly include sepsis, mastitis, retained placenta, joint diseases, acidosis, enteritis, pneumonia and ketosis (1). Even calving was shown as a physiological cause of oxidative stress in healthy cows (11), recent studies in oxidative stress and antioxidant status in ruminant have been focused on periparturient diseases (5). Dairy cattle are known more susceptible to a variety of metabolic and infectious diseases during the transition period than in lactation (26). It was determined that oxidative stress can occur during transition period, and it can contribute to some periparturient infectious and metabolic diseases (1). 
Clarity and understanding of the pathophysiology of oxidative stress in ruminant should allow the design of specific antioxidant treatment (5).

Displacement of abomasum (DA) is one of the most common non-infectious diseases in dairy cows in early lactation. DA is a multifactorial disease where the abomasum is dilated as a result of gas accumulation and dislocated to the left (LDA, left-displaced abomasum) or to the right (RDA, right-displaced abomasum and AV, abomasal volvulus) in the abdominal cavity (6). Approximately $85 \%$ of the incidences are LDA (12). Abomasal volvulus would be a rarity in LDA due to the location of the displaced abomasum. However, abomasal volvulus accompanies RDA in several cases. As such, cows with abomasal volvulus demonstrate a more severe clinical signs and clinicopathology compared to LDA and to RDA (23).

Basically, the oxidative stress-related studies presented in this study are not new, however, measurement of serum total oxidative status (TOS) and total antioxidant capacity (TAC) with calculation an oxidative stress index (OSI) value have not been used in cows with right- and left-sided abomasal displacement. Therefore, the aim of this study was to investigate oxidative stress and antioxidant status by detection of serum TOS, TAC, and OSI, and lipid profile of cows with left and right-sided abomasal displacement in cows.

\section{Materials and Methods}

The current study was performed in accordance with legislation specified by the guiding principles in the care and use of animals and Mustafa Kemal University protocols for animal studies.

Animals; A total of twenty-two Holstein dairy cows with right- or left-sided abomasal displacement (LDA $(n=11)$ and RDA without volvulus $(n=11))$ and 10 healthy cows as controls were used in this study. All animals were subjected to similar environmental, managemental and feeding conditions. The range age of the cows was 4-6 years (2-4 calving). All cows were within the early postpartum which varied from 1 to 8 weeks (mean 4 weeks) of postpartum. All animals were fed high-energy and low fibre content. Cows examined for postpartum diseases (mastitis, metritis, retention secundinarium, hoof problems and clinical ketosis, etc.) and those with any of these diseases were excluded.

Routine physical examination, laboratory tests, and specific DA tests (ping on auscultation and percussion, fluid splashing, liptak test, ultrasonography, and lost percussion area of liver in RDA) were performed. Dairy cows with presumptive clinical DA were sent to the Surgery Clinic of Veterinary Medicine for confirmation.

Blood sampling; Total of $8 \mathrm{ml}$ blood samples were collected via jugular veinpuncture into silicone gel coated vacutainer tubes before laparotomy. Following clotting, serum samples were separated by centrifugation at $3000 \mathrm{rpm}$ for 10 minutes at room temperature and stored at $-18^{\circ} \mathrm{C}$ until biochemical analyses.

Sample analysis; Total antioxidant and oxidant capacities were determined colorimetrically (PowerWave XS, BioTek Instrument, Bedfordshire/UK) using a commercial kit (Rel Assay Diagnostic, Gaziantep, Turkey) as previously described by Durgut et al (7). The TAC of the serum was determined using a novel automated measurement method developed elsewhere (8, 9). The assay measures the antioxidative effect of the sample against potent-free radical reactions that are initiated by the hydroxyl radical produced. The results are expressed as $\mu$ mol Trolox equivalent/litre.

Total oxidant status levels were measured using commercially available kits (Rel Assay Diagnostic, Gaziantep, Turkey). In the new method, oxidants present in the sample oxidized the ferrousion-o dianisidine complex to ferric ion. The oxidation reaction was enhanced by glycerol molecules abundantly present in the reaction medium. The ferric ion produced a coloured complex with xylenol orange in an acidic medium. The color intensity, which was measured spectrophotometrically, was related to the total amount of oxidant molecules present in the sample. The assay was calibrated with hydrogen peroxide $\left(\mathrm{H}_{2} \mathrm{O}_{2}\right)$ and the results were expressed in terms of micromolar $\mathrm{H}_{2} \mathrm{O}_{2}$ equivalent per liter (mmol $\mathrm{H}_{2} \mathrm{O}_{2}$ equivalent/L) (9). The percentage ratio of TOS to TAS indicated OSI, an indicator of the degree of oxidative stress $(8,9)$. To perform the calculation, the resulting unit of TAS (mmol Trolox equivalent/litre) was converted to $\mu \mathrm{mol}$ equivalent/litre and the OSI value was calculated using the following formula: OSI $=[(\mathrm{TOS}, \mu \mathrm{mol} / \mathrm{L}) /(\mathrm{TAC}, \mathrm{mmol}$ Trolox equivalent/L) x100] (9).

Serum total cholesterol (TC) and triglyceride (TG) concentrations were determined using enzymatic colorimetric kits (Roche diagnostics GmbH, Indianapolis, USA) by Hitachi 747 Automatic Analyzer (Boehringer Mannheim Germany). High density lipoprotein (HDL) was measured using precipitation method and low density lipoprotein (LDL) was also calculated using Friedewald's formula.

Statistical analysis; The results were analyzed by an one-way analysis of variance (ANOVA) followed by the Duncan test for multiple comparisons using computer software, SPSS Version 15.0 for Windows. The data were presented as mean \pm standard deviation. The significance level was set as $\mathrm{p}<0.05$.

\section{Results}

Clinical examination of affected cows indicated anorexia, sudden drop of milk yield, rare defecation and scanty pasty faeces. In the ausculopercussion of the left and right abdominal wall, high-pitched resonant pings 
Table 1. The effect of abomasum displacement on oxidative status and lipid metabolism in dairy cows. Tablo 1. Sağlıklı kontrol, RDA ve LDA'lı sığırlarda bazı lipid parametreleri ve OSI, TAS, TOS serum ortalamaları.

\begin{tabular}{|c|c|c|c|c|c|}
\hline & $\begin{array}{c}\text { LDA } \\
(\mathrm{n}: 11)\end{array}$ & $\begin{array}{c}\text { RDA } \\
\text { (n: 11) }\end{array}$ & $\begin{array}{c}\text { Control } \\
(\mathrm{n}: 10)\end{array}$ & RSD & $\mathrm{P}$ \\
\hline TOS ( $\mu$ mol H2O2 Equiv./L) & $10.35^{\mathrm{a}}$ & $15.89^{\mathrm{b}}$ & $11.41^{\mathrm{a}}$ & 3.49 & 0.001 \\
\hline TAC (mmol Trolox Equiv./L) & 0.88 & 0.77 & 0.90 & 0.17 & 0.112 \\
\hline OSI (arbitrary unit) & $12.23^{\mathrm{a}}$ & $17.77^{\mathrm{b}}$ & $13.14^{\mathrm{a}}$ & 4.05 & 0.001 \\
\hline $\mathrm{TC}(\mathrm{mmol} / \mathrm{L})$ & $92.00^{\mathrm{a}}$ & $98.73^{\mathrm{a}}$ & $151.00^{\mathrm{b}}$ & 52.46 & 0.011 \\
\hline $\operatorname{LDL}(\mathrm{g} / \mathrm{L})$ & $40.55^{\mathrm{a}}$ & $48.91^{\mathrm{a}}$ & $92.00^{\mathrm{b}}$ & 30.77 & 0.001 \\
\hline $\mathrm{HDL}(\mathrm{g} / \mathrm{L})$ & $48.33^{\mathrm{a}}$ & $47.00^{\mathrm{a}}$ & $72.60^{\mathrm{b}}$ & 18.93 & 0.001 \\
\hline $\mathrm{TG}(\mathrm{mmol} / \mathrm{L})$ & $15.60^{\mathrm{b}}$ & $14.09^{\mathrm{b}}$ & $7.00^{\mathrm{a}}$ & 6.16 & 0.001 \\
\hline
\end{tabular}

$\overline{\mathrm{a}, \mathrm{b}}$ differences are statistically significant among groups marked with different letters on the same line $(\mathrm{P}<0.05)$. LDA: Left-sided abomasal displacement, RDA: Right-sided abomasal displacement, RSD: Residual standard deviation, TOS: Total oxidant status, TAC: Total antioxidant capacity, OSI: Oxidative stress index, TC: Total cholesterol, LDL: Low density lipoprotein, HDL: High density lipoprotein, TG: Triglycerides.

${ }^{\mathrm{a}, \mathrm{b}}$ farklılıklar, aynı satır üzerinde farklı harflerle belirlenmiş gruplar arasındaki istatislik önemlidir $(\mathrm{P}<0.05)$. LDA:Sola abomasum deplasmanı, RDA:Sağa abomasum deplasmanı, RDS:Rezidual standart sapma, TOS:Total oksidatif seviye, TAC:Total antioksidan kapasite, OSI:Oksidatif stress indeks, TC:Total kolestrol, LDL:Düşük dansiteli lipoproteinler, HDL:Yüksek dansiteli lipoproteinler, TG:Trigliserid.

and splashing sounds were heard on over the last three ribs.

Serum mean concentration of TOS and OSI values were significantly higher $(\mathrm{p}=0.001)$ in cows with RDA than LDA and healthy controls. A significant decrease of serum TC, HDL and LDL levels, while significantly increased $(p=0.001)$ TG levels were observed in both DA groups compared to control animals. The results of mean serum TOS, TAC and OSI values in cattle with LDA, RDA and healthy controls are presented in Table 1.

\section{Discussion and Conclusion}

The study was designed to evaluate the serum oxidative and antioxidant status, and degree of oxidative stress (oxidative stress index, OSI) in cows with displaced abomasum. Besides these, lipid metabolism of dairy cows was also determined. Basically, the oxidative stress-related studies presented in this study are not new. The methods that were in fact firstly described in 20042005 by Erel $(8,9)$ and the calculation of an oxidative stress index that was already described by Celi et al (4) and currently used by many scientists. To the best of our knowledge, there is a limited study on determination of the oxidative status and degree of oxidative stress using by TOS and OSI in ruminant (7). Serum or plasma concentrations of different oxidant species (malondialdehyde, nitric oxide) and antioxidant concentration (superoxide dismutase, glutathione peroxidase, catalase, vitamin $\mathrm{E}$ and selenium) can be measured by direct or indirect methods separately in laboratories. However, separate measurement of each parameter has advantages and disadvantages, and thus fail to provide an overall measurement of cumulative oxidative and antioxidant status. The individual measurements are time-consuming, labour-intensive, costly and require complicated techniques (14).

DA is one of the most important non-infectious diseases in high yielding dairy cows in early lactation. Oxidative stress is shown to be involved in the pathogenesis of this disease (10). Many researchers have studied determinations of antioxidant status separately by detection of serum superoxide dismutase, glutathione peroxidase, vitamin $\mathrm{E}$ and selenium levels or total antioxidant status in cattle with DA $(15,19,22)$. It is noteworthy that Maden et al (18) recently published results similar to the ones presented in this manuscript on oxidative stress associated with displaced abomasum (i.e. higher oxidative stress in RDA than LDA by using a different biomarker to assess the oxidative stress=malondialdehyde). To the author's knowledge; however, the methods we used (measurement of TOS and TAC with calculation an OSI) have not been used in cows with right- and left-sided abomasal displacement. It is also new that LDA and RDA cases were compared with these methods. In addition, determination of TOS and TAC levels are reported simple, cost-effective, reliable and sensitive, and do not interact with serum components such as lipids, bilirubin or anticoagulants (8, 9).

Hasanpour et al. (15) used other methods rather than used in the current study and they concluded that the antioxidant status in cows with DA was lower than that of healthy ones as shown in the study. On the contrary to Hasanpour et al. (15), similar TAC levels were found in cows with left-sided abomasal displacement and healthy controls in our study. Similar to our study, Furll et al. (10) reported that serum TAC in cows with DA was not different from healthy cows. According to these results, 
cows with right-sided abomasal displacement without torsion and volvulus showed higher TOS and OSI values than cows with LDA and healthy controls, while there were no differences in their TAC values. As OSI is calculated value dividing TOS by TAC, it is not surprising that the OSI-related conclusion is the same as made on TOS results. Hasanpour et al. (15) and Sattler et al. (25) reported that the decrease in serum antioxidants is due to an insufficient antioxidant levels, or-the potential role of lack of antioxidants (27) in development of abomasal displacement. On the contrary, the results in the current study could imply that right-sided abomasal displacement may result in greater oxidative stress, thus forming more free radicals than left-sided abomasal displacement; because of abomasal tension and increased intraluminal pressure in right-sided.

The results presented in the current study showed that LDL, HDL, and total concentrations significantly decreased in the cows with DA when compared to healthy controls (Table 1). The LDL, HDL and cholesterol changes are in agreement with other results of experiments carried out on high yielding cows with energy deficiency at postpartum $(2,3,16,24)$. Lower LDL, HDL and cholesterol levels in the current study may be due to impairment of lipid metabolism. It is reported that low cholesterol and lipoprotein concentrations have been associated with metabolic disorders (16) or hepatic lipidosis (2). In addition, the decrease of serum LDL could have resulted from the reduction of VLDL synthesis or release by the liver, and decrease of serum HDL may be associated with low concentrations of cholesterol (24). In addition, fatty liver syndrome near calving indicated that stress (the sensitivity to lipolytic signals by epinephrine and norepinephrine) induced by environmental conditions might promote triglyceride accumulation (13). Related with these studies, dairy cows in early lactation with abomasal displacement but without apparent signs of metabolic disorders, triglyceride concentration significantly increased when compared to healthy animals in the present study.

It is known that ketosis and fatty liver in periparturient cattle are often associated with DA, and it is thought that these three disorders are interrelated. It was reported that oxidative stress might contribute to some periparturient infectious, metabolic diseases (1), or abomasal tissue damage because of displacement (obstruction and increased luminal pressure) in DA cases (18). Recently, Oliveira et al. (20, 21) reported that oxidative stress increased liver steatosis, and could be an important step in the pathogenesis of non-alcoholic fatty liver. Although it is not clear, low cholesterol and lipoprotein concentrations have been associated with sub clinical metabolic disorders (16) or hepatic lipidosis, which might contribute to right-sided abomasal displacement. Oxidative stress could play an important role in the aetiology and pathogenesis of periparturient metabolic diseases in dairy cows. Further studies are necessary to establish the role of oxidative stress in fatty liver and related metabolic diseases in cows.

In conclusion, this is the first study to evaluate serum total oxidative status and degree of oxidative stress in cattle with DA by detection of TOS levels and OSI value. The results of the current study showed that dairy cows with right-sided abomasal displacement had higher oxidative stress than left sided abomasal displacement, because of tissue damage caused by abomasal tension and increased intraluminal pressure in right-sided abomasal displacement. However, there was no alteration of serum antioxidant status in dairy cows with LDA and RDA.

\section{References}

1. Bernabucci U, Ronchi B, Lacetera N, et al. (2005): Influence of body condition score on relationships between metabolic status and oxidative stress in periparturient dairy cows. Journal of Dairy Science, 88, 2017-2026.

2. Bobe G, Young JW, Beitz DC (2004): Invited Review: Pathology, etiology, prevention, and treatment of fatty liver in dairy cows. Journal of Dairy Science, 87, 31053124.

3. Cameron REB, Dyk PB, Herdt TH, et al. (1998): Dry cow diet, management, and energy balance as risk factors for displaced abomasum in high producing dairy herds. Journal of Dairy Science, 81, 132-139.

4. Celi P (2011a): Oxidative stress in ruminants. In: oxidative stress in applied basic research and clinical practice (Ed. D. Armstrong). Humana Press, pp.191-230.

5. Celi P (2011b): Biomarkers of oxidative stress in ruminant medicine. Immunopharmacology Immunotoxicology, 332, 233-240.

6. Constable PD, Miller GY, Hoffsis GF, et al. (1992): Risk factors for abomasal volvulus and left abomasal displacement in cattle. American Journal Veterinary Research, 53, 1184-1192.

7. Durgut R, Ataseven VS, Ozturk AS, et al. (2013): Evaluation of total oxidative stress and total antioxidant status in cows with natural bovine herpesvirus-1 infection. Journal of Animal Science, 91, 3408-3412.

8. Erel O (2004): A novel automated method to measure total antioxidant response against potent free radical reactions. Clinical Biochemistry, 37, 112-119.

9. Erel O (2005): A new automated colorimetric method for measuring total oxidant status. Clinical Biochemistry, 38, 1103-1111.

10. Furll M, Dabbagh MN, Kirbach H, et al. (2003): The anti-oxidative state before and after a diagnosed abomasal displacement in cows. Acta Veterinaria Scandinavica, 44, 37.

11. Gaal T, Ribiczeyne-Szabo P, Stadler K, et al. (2006): Free radicals, lipid peroxidation and the antioxidant system in blood of cows and newborn calves around calving. Comparative Biochemical Physiology Part B, 143, 391-396. 
12. Geishauser T (1995): Abomasal displacement in the bovine - a review on character, occurrence, aetiology and pathogenesis. Zentralbl Veterinaermed A, 42, 229-251.

13. Gerloff BJ, Herdt TH, Emery RS (1986): Relationship of hepatic lipidosis to health and performance in dairy cattle. Journal American Veteterinary Medical Associotion, 188, 845-850.

14. Harma M, Harma M, Erel O (2005): Measurement of the total antioxidant response in preeclampsia with a novel automated method. European Journal of Obstetrics Gynecology Reproductive Biology, 118, 47-51.

15. Hasanpour A, Saranjam N, Amuoghli Tabrizi B (2011): Antioxidant concentration status in the serum of cows with left displacement abomasom. Global Veterinaria, 7, 478481.

16. Itoh N, Koiwa M, Hatsugaya A, et al. (1998): Comparative analysis of blood chemical values in primary ketosis and abomasal displacement in cows. Journal of Veterinary Medicine Serie A, 45, 293-298.

17. Lykkesfeldt J, Svendsen O (2007): Oxidants and antioxidants in disease: oxidative stress in farm animals. Veterinary Journal, 173, 502-511.

18. Maden M, Ozturk SA, Bulbul A, et al. (2012): Acute phase proteins, oxidative stress and enzyme activities of blood serum and peritoneal fluid in abomasal displacement cases. Journal of Veterinary Internal Medicine, 26, 1470-1475.

19. Mudron P, Rehage J, Sallmann HP, et al. (1997): Plasma and liver alpha-tocopherol in dairy cows with left abomasal displacement and fatty liver. Zentralbl Veterinarmed. A, 44, 91-97.

20. Oliveira CP, Da Costa Gayotto LC, Tatai C, et al. (2005): Oxidative stress in the pathogenesis of nonalcoholic fatty liver disease, in rats fed with a cholinedeficient diet. Journal of Cellular and Moleculer Medicine, 6, 399-406.
21. Oliveira CP, Coelho AM, Barbeiro HV, et al. (2006): Liver mitochondrial dysfunction and oxidative stress in the pathogenesis of experimental nonalcoholic fatty liver disease. Brazilian Journal of Medical and Biological Research, 39, 189-194.

22. Qu Y, Lytle K, Traber MG, et al. (2013): Depleted serum vitamin $E$ concentrations precede left displaced abomasum in early-lactation dairy cows. Journal Dairy Science, 96, 3012-3022.

23. Radostits OM, Gay CC, Hinchliff K, et al. (2007): Veterinary Medicine. A textbook of the diseases of cattle, horse, sheep, pigs and goats.10 h. Ed., Elsevier Publisher, Amstrerdam.

24. Rayssiguier Y, Mazur A, Gueux E, et al. (1998): Plasma lipoproteins and fatty liver in dairy cows. Research in Veterinary Science, 45, 389-393.

25. Sattler T, Fuerll M (2002): Antioxidative status (SOD, GPX) of cows with displaced abomasum, clinical significance and influence of the treatment with antioxidants. XXII. World Buiatrics Congress Proocedings, Hannover, p:397-456.

26. Sordillo LM, O'boyle N, Gandy JC, et al. (2007): Shifts in thioredoxin reductaseactivity and oxidant status in mononuclear cells obtained from transition dairy cattle. Journal of Dairy Science, 90, 1186-1192.

27. Van Winden S (2002): Displacement of the abomasum in dairy cows -risk factors and pre-clinical alterations. Dissertation Utrecht University. Faculty of Veterinary Medicine. ISBN90-393-3180-4. pp:99.

Geliş tarihi: 25.11.2014 / Kabul tarihi: 03.06.2015

\author{
Address for correspondence: \\ Dr. Ramazan Durgut \\ University of Mustafa Kemal, \\ Faculty of Veterinary Medicine, \\ Department of Internal Medicine, Hatay, TURKEY. \\ e-mail:rdurgut@gmail.com
}

